\title{
MICROSTRUCTURAL CHANGES OF ECAP-PROCESSED MAGNESIUM ALLOY AZ91 DURING CYCLIC LOADING AT DIFFERENT STRESS-AMPLITUDE LEVELS
}

\author{
MIKROSTRUKTURNE SPREMEMBE Z ECAP POSTOPKOM \\ PROCESIRANE MAGNEZIJEVE ZLITINE MED CIKLIČNIM \\ OBREMENJEVANJEM PRI RAZLIČNIH NIVOJIH NAPETOSTNE \\ AMPLITUDE
}

\author{
Roman Štěpánek ${ }^{1}$, Libor Pantělejev ${ }^{1}$, Ondřej Man¹, Mario Guagliano², Maurizio Vedani² \\ Ehsan Mostaed ${ }^{2}$ \\ ${ }^{1}$ Institute of Materials Science and Engineering, Faculty of Mechanical Engineering, Brno University of Technology, \\ Technická 2896/2, 616 69, Brno, Czech Republic \\ ${ }^{2}$ Politecnico di Milano, Department of Mechanichal Engineering, Via Giuseppe La Masa 1, 20156, Milan, Italy \\ stepanek.r@fme.vutbr.cz
}

Prejem rokopisa - received: 2017-06-28; sprejem za objavo - accepted for publication: 2017-11-03

doi:10.17222/mit.2017.087

\begin{abstract}
Microstructural changes of magnesium alloy AZ91 after fatigue loading in the EX-ECAP state were evaluated using EBSD. It was found that both the number fraction of low-angle boundaries and parameter KAM decreased after the testing at a stress amplitude of $160 \mathrm{MPa}$ but started to increase with the increasing stress amplitude. This behaviour can be explained with a mutual influence of dislocation accumulation (which is stronger with a higher stress amplitude) and dynamic softening (which is weaker with a decreasing number of cycles/cycles to failure). The average grain size remained almost unchanged except at a stress amplitude of $180 \mathrm{MPa}$, which could have been caused by certain conditions allowing an ideal development of both mentioned phenomena.

Keywords: magnesium alloy, ECAP, EBSD, fatigue loading

$\mathrm{V}$ pričujočem članku avtorji opisujejo ovrednotenje mikrostrukturnih sprememb magnezijeve zlitine AZ91 z EBSD metodo zaradi utrujanja po procesiranju z ECAP-postopkom. Ugotovili so, da se tako delež malo kotnih mej kot tudi parameter razlik y kristalografski orientaciji kristalnih zrn (KAM; angl.: Kernel Average Misorientation) znižujeta po testiranju pri napetostni amplitudi toda pričneta naraščati z naraščajočo napetostno amplitudo. To obnašanje si je moč razložiti z istočasnim vplivom kopičenja dislokacij, (ki je intenzivnejše pri višjih napetostnih amplitudah) in dinamičnim mehčanjem, (ki je manjše pri manjšem razmerju med dejanskim številom ciklov in številom ciklov do porušitve). Povprečna velikost kristalnih zrn je ostala skoraj nespremenjena pri napetostni amplitudi $180 \mathrm{MPa}$, kar je lahko posledica specifičnih pogojev, ki omogočajo idealen potek obeh omenjeni pojavov (mehanizmov).

Ključne besede: zlitina na osnovi magnezija, ekstremno močna plastična deformacija (SPD) dosežena z enokanalnim pravokotnim procesiranjem (ECAP), preiskovalna metoda na osnovi uklona povratno sipanih elektronov (EBSD), utrujanje oz. dinamično (ciklično) obremenjevanje
\end{abstract}

\section{INTRODUCTION}

Magnesium and its alloys, as one of the lightest structural material, is used in applications where weight reduction is required. However, mechanical properties of the magnesium alloys in the as-cast state are usually unsatisfactory for any advanced application due to its coarse grain structure. ${ }^{1,2}$ Although conventional extrusion is often sufficient to achieve suitable mechanical properties, further grain-refinement methods are sought to meet higher demands. 3,4

Severe-plastic-deformation (SPD) methods seem to be suitable for achieving ultrafine-grain (UFG) or nearly UFG microstructures, which often exhibit superior mechanical properties. Equal-channel angular pressing (ECAP) is one of the most used SPD methods, especially due to its good controllability of the final microstructure. ${ }^{4,5}$ The materials processed via ECAP (or generally with any SPD method) exhibit a certain microstructural instability caused by high inner energy and unstable (grain) boundaries. The microstructural stability loss can occur during a thermal exposition ${ }^{6,7}$ or mechanical loading (predominantly fatigue loading). ${ }^{8,9}$ The instability can be manifested as grain coarsening connected with a decrease in the mechanical properties, which can be lower than the properties of an unprocessed, virgin material.

The response of fine and ultrafine-grained microstructures to cyclic loading is very ambiguous and depends on various parameters. Even nearly the same alloys can exhibit different responses depending predominantly on the details of the treatment processes although the chemical compositions and microstructures of the materials are, in principle, identical. ${ }^{10}$ Nevertheless, although UFG materials do not exhibit a uniform behaviour during cyclic loading, their responses are 


\section{R. ŠTĚPÁNEK et al.: MICROSTRUCTURAL CHANGES OF ECAP-PROCESSED MAGNESIUM ALLOY AZ91 ...}

usually connected with a certain degree of microstructural changes such as grain coarsening or a creation and annihilation of low-angle boundaries connected with softening/hardening processes. ${ }^{11-13}$

The response of the microstructure of magnesium alloy AZ91 processed with ECAP to cyclic loading is analysed in this paper.

\section{EXPERIMENTAL PART}

The experimental material was an extruded magnesium alloy AZ91 of commercial quality with a chemical composition given in Table 1. The alloy was further processed at Politecnico di Milano with ECAP at $200{ }^{\circ} \mathrm{C}$ using route $\mathrm{B}_{\mathrm{C}}$, with a die having an angle between the intersecting channels of $110^{\circ}$ (the EX-ECAP state). The dimensions of the billets obtained with the ECAP process were a 10-mm diameter and a length of approximately $90 \mathrm{~mm}$. The initial microstructural analysis was performed using a light microscope Zeiss Axio Observer Z1m and a scanning electron microscope Zeiss Ultra Plus with an Oxford Instruments NordlysNano EBSD detector.

Fatigue testing was performed on cylindrical samples with a diameter of $6 \mathrm{~mm}$ and gauge length of $20 \mathrm{~mm}$ fabricated from the EX-ECAP billets. Rotating bendingfatigue tests were conducted at room temperature in the load-controlled regime with a symmetrical loading cycle with a frequency of $2000 \mathrm{~min}^{-1}$ using an Italsigma 2TM831 testing machine. The changes in the microstructure were assessed by means of EBSD using a scanning electron microscope Zeiss Ultra Plus. The EBSD analysis was performed using a square grid with a step length of $0.1 \mu \mathrm{m}$. The accelerating voltage was $20 \mathrm{kV}$ and the beam current was 3.3-8.6 nA.
Three specific parameters - grain size (GS), low-angle boundaries (LAB), number fraction and kernel average misorientation (KAM) were selected to quantify the microstructural changes induced with fatigue testing. A grain was defined as an area separated from its surrounding by a boundary with a misorientation of at least $5^{\circ}$ and consisting of at least 5 pixels. The grain diameter was defined as the diameter of an equivalent circle with the same area as that of a detected grain (an equivalent grain diameter). The misorientation angle was defined in a range of $1-100^{\circ}$ (the estimated measurement accuracy $<1^{\circ}$ ); the threshold between low- and highangle boundary (HAB) was set as $15^{\circ}$. The KAM distribution was calculated within an angular range of $0-3^{\circ}$ over the second neighbour perimeter including interlaid pixels; the modal values were then taken for comparison. For the evaluation of the structural changes due to fatigue loading, three areas of approximately $10800 \mu \mathrm{m}^{2}$ each were considered for each analysed sample.

\section{RESULTS}

The microstructure of the analysed alloy contains large areas consisting of fine grains filled with very fine $\mathrm{Mg}_{17} \mathrm{Al}_{12}$ phase particles, whose morphology is partly related to the grain layout after the first pass of ECAP (Figure 1a - the dark areas). According to the EBSD results, the matrix of the material is nearly ultrafine grained, but with a few residual large grains (Figure 1b). Nevertheless, the calculated average grain size is $1.6 \mu \mathrm{m}$.

Based on the fatigue-test results (the fatigue limit determined for $10^{7}$ cycles is $176 \mathrm{MPa}$ ), samples loaded at stress amplitudes of (160, 180, 200 and 220) MPa were chosen for a microstructural analysis after the tests.

The initial values of the analysed parameters (average grain size $-1.61 \mu \mathrm{m}, \mathrm{LAB}$ number fraction $-63.1 \%$,

Table 1: Chemical composition of the used AZ91 alloy, in mass fractions, $(w / \%)$

\begin{tabular}{|c|c|c|c|c|c|c|c|c|}
\hline & $\mathrm{Al}$ & $\mathrm{Cu}$ & $\mathrm{Fe}$ & $\mathrm{Mn}$ & $\mathrm{Si}$ & $\mathrm{Zn}$ & other (total) & $\mathrm{Mg}$ \\
\hline AZ91 extruded & 8.700 & 0.001 & 0.003 & 0.200 & 0.040 & 0.670 & $<0.030$ & balance \\
\hline
\end{tabular}

Table 2: Changes in the observed micro- and substructural parameters after fatigue tests

\begin{tabular}{|c|c|c|c|c|c|c|c|}
\hline \multirow{3}{*}{\multicolumn{2}{|c|}{ initial state }} & \multirow{2}{*}{\multicolumn{2}{|c|}{$\begin{array}{c}\mathrm{GS}(\mu \mathrm{m}) \\
1.61\end{array}$}} & \multirow{2}{*}{\multicolumn{2}{|c|}{ LAB (\%) }} & \multicolumn{2}{|c|}{ KAM mode $\left(^{\circ}\right)$} \\
\hline & & & & & & \multicolumn{2}{|c|}{0.25} \\
\hline & & absolute value & $\Delta \mathrm{GS}$ & absolute value & $\triangle \mathrm{LAB}$ & absolute value & $\triangle \mathrm{KAM}$ \\
\hline \multirow{3}{*}{$\begin{array}{c}\text { sample } 10 \\
\sigma_{\mathrm{a}}=160 \mathrm{MPa} \\
N=16651000\end{array}$} & site 1 & 1.46 & -0.15 & 45.70 & -17.40 & 0.15 & -0.10 \\
\hline & site 2 & 1.70 & 0.09 & 53.40 & -9.70 & 0.15 & -0.10 \\
\hline & site 3 & 1.67 & 0.06 & 53.10 & -10.00 & 0.25 & 0.00 \\
\hline \multirow{3}{*}{$\begin{array}{c}\text { sample } 11 \\
\sigma_{\mathrm{a}}=180 \mathrm{MPa} \\
N=7063000\end{array}$} & site 1 & 2.28 & 0.67 & 68.80 & 5.70 & 0.35 & 0.10 \\
\hline & site 2 & 2.03 & 0.42 & 69.70 & 6.60 & 0.35 & 0.10 \\
\hline & site 3 & 1.80 & 0.19 & 70.30 & 7.20 & 0.25 & 0.00 \\
\hline \multirow{3}{*}{$\begin{array}{c}\text { sample } 5 \\
\sigma_{\mathrm{a}}=200 \mathrm{MPa} \\
N_{\mathrm{f}}=34000\end{array}$} & site 1 & 1.64 & 0.03 & 70.60 & 7.50 & 0.35 & 0.10 \\
\hline & site 2 & 1.34 & -0.27 & 74.90 & 11.80 & 0.35 & 0.10 \\
\hline & site 3 & 1.69 & 0.08 & 58.70 & -4.40 & 0.25 & 0.00 \\
\hline \multirow{3}{*}{$\begin{array}{c}\text { sample } 4 \\
\sigma_{\mathrm{a}}=220 \mathrm{MPa} \\
N_{\mathrm{f}}=24000\end{array}$} & site 1 & 1.78 & 0.17 & 83.20 & 20.10 & 0.45 & 0.20 \\
\hline & site 2 & 1.79 & 0.18 & 76.40 & 13.30 & 0.35 & 0.10 \\
\hline & site 3 & 1.95 & 0.34 & 81.30 & 18.20 & 0.35 & 0.10 \\
\hline
\end{tabular}



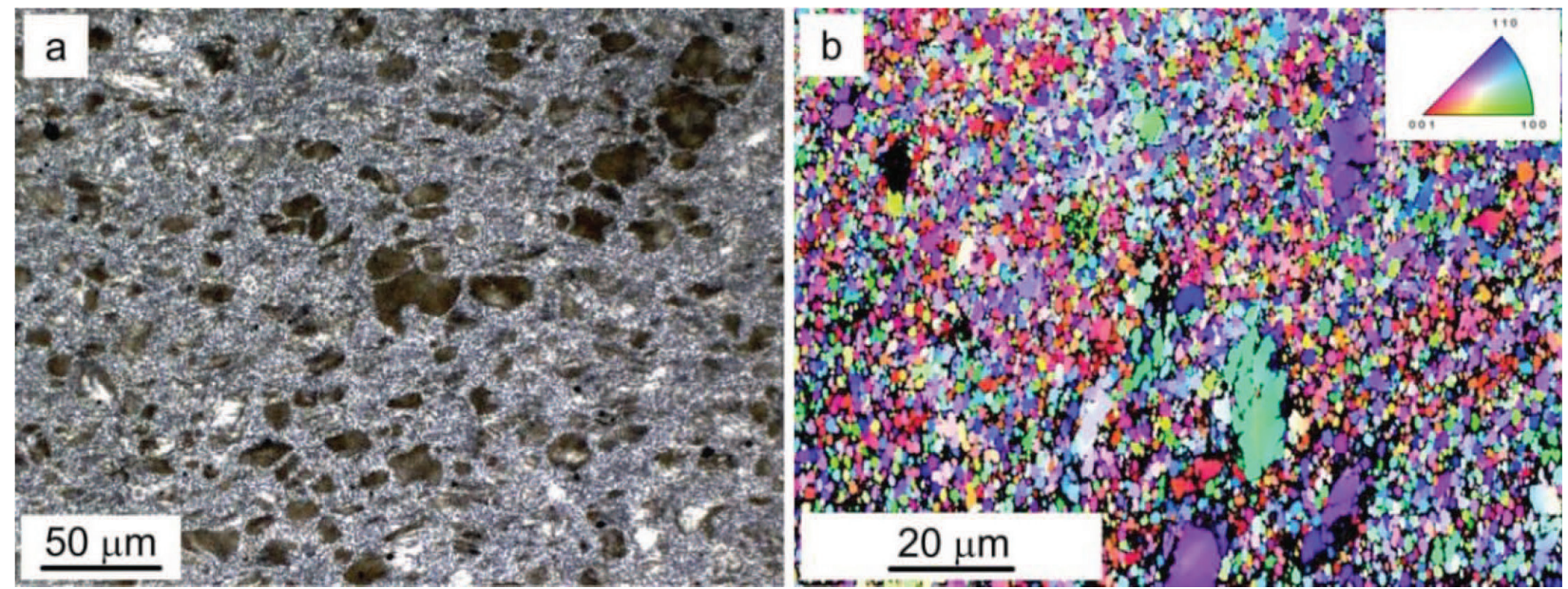

Figure 1: Microstructure of AZ91 alloy (EX-ECAP state): a) light microscope, b) IPF map (EBSD - SEM)

KAM mode $-0.25^{\circ}$, Table 2) were calculated as the average values of more than 25 areas on the same alloy in the virgin state (EX-ECAP). According to the EBSD analysis, the average grain size remained almost unchanged after the loading at $160 \mathrm{MPa}$ and $200 \mathrm{MPa}$, while it increased at $220 \mathrm{MPa}$ and was even higher at $180 \mathrm{MPa}$. Gained inverse-pole figure maps (Figure 2) clearly show that at the stress amplitude of $220 \mathrm{MPa}$, the grain coarsening is rather homogeneous in the whole investigated area, while at the stress amplitude of 180 $\mathrm{MPa}$, the coarsening is more anisotropic with the grains elongated in a certain direction. Even at $180 \mathrm{MPa}$, when the grain coarsening is the most pronounced, the absolute change in the grain diameter is lower than $1 \mu \mathrm{m}$ (Table 2).

The number fraction of LAB decreased at $160 \mathrm{MPa}$ but started to increase with the increasing stress amplitude (Table 2). The KAM mode (which can be connected with the local lattice distortion of the material) exhibited a trend similar to the changes of the LAB number fraction - it decreases at lower stress amplitudes and increases at higher stress amplitudes (Table 2).
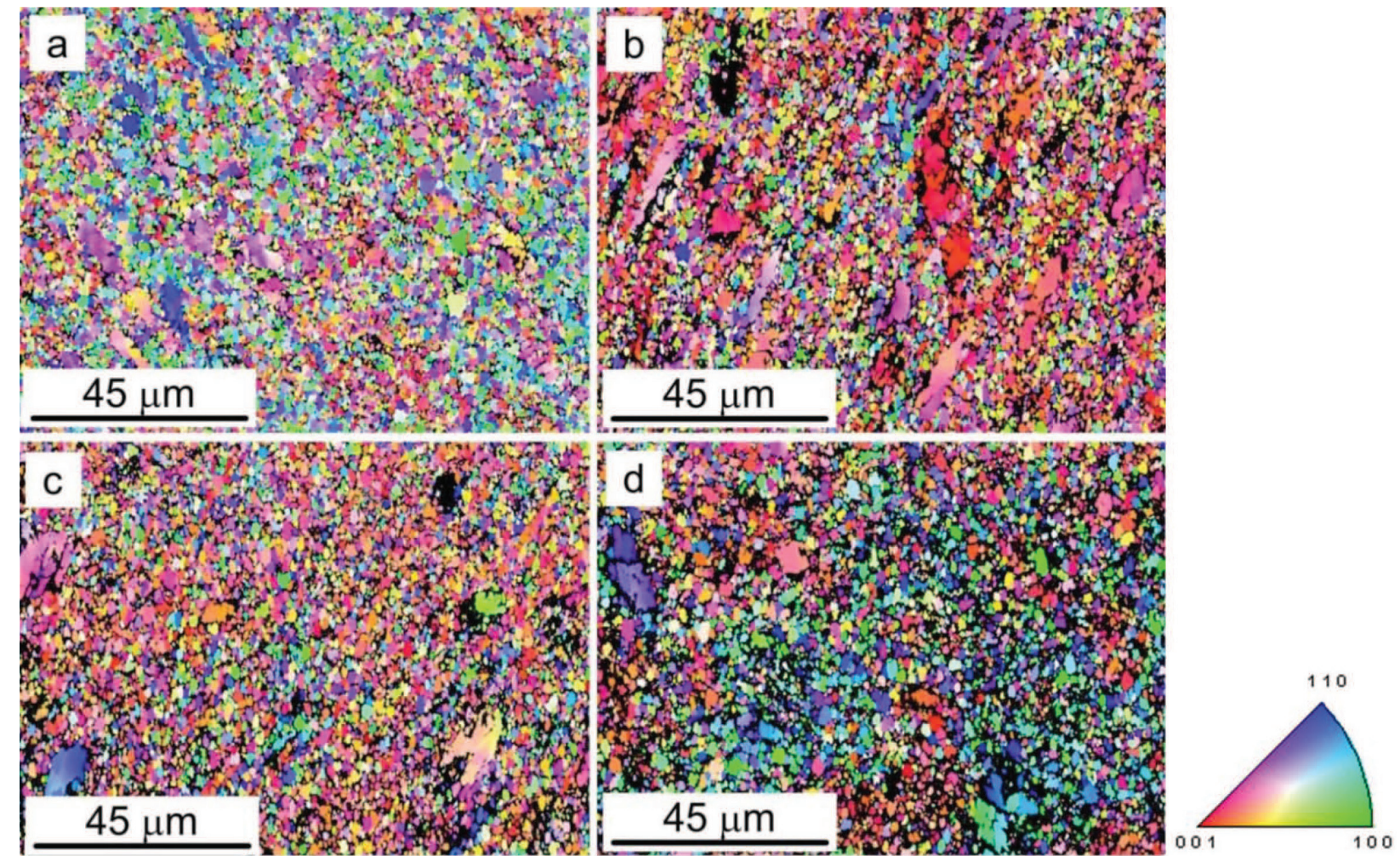

Figure 2: IPF maps of AZ91 alloy after the fatigue test: a) $\left.\sigma_{\mathrm{a}}=160 \mathrm{MPa}, \mathrm{b}\right) \sigma_{\mathrm{a}}=180 \mathrm{MPa}$, c) $\sigma_{\mathrm{a}}=200 \mathrm{MPa}$, d) $\sigma_{\mathrm{a}}=220 \mathrm{MPa}$ 


\section{DISCUSSION}

The clear trend in the LAB and KAM change behaviour can be explained with two significant processes that occur in the materials (especially in the fine- and ultrafine-grained ones) during the cyclic loading. The first process is a dislocation accumulation with an increasing overall dislocation density, which can lead up to an increased number of LAB and also an increase in the local lattice distortion and KAM mode. ${ }^{14}$ The second process, occurring during the cyclic loading, is dynamic softening, driven by the cyclic loading of the material. ${ }^{14}$ Due to their nature, both processes are mutually counteractive. At lower levels of the stress amplitude, the effect of the dislocation accumulation is weaker, while dynamic-softening processes are more pronounced due to a higher number of the loading cycles so that the overall effect of the cyclic loading on the (sub) structure would be manifested by a decrease in both the LAB number fraction and KAM mode. With the increasing stress amplitude, dislocation accumulation becomes stronger and the number of cycles to failure decreases so that the dynamic-softening processes cannot be developed as in the previous case; therefore, the overall change in the LAB number fraction and KAM mode start increasing and the increase is more pronounced with the higher stress amplitude (and lower number of cycles to failure). This common assumption is supported by the results of an image-quality (IQ) analysis (the value of IQ can be connected to the overall dislocation density at the qualitative level - a higher dislocation density results in a lower diffraction and lower IQ), which indicate a decrease of IQ with the increasing stress amplitude (stress amplitude/average IQ: $160 \mathrm{MPa} / 105,180 \mathrm{MPa} / 68,200$ $\mathrm{MPa} / 65,220 \mathrm{MPa} / 57)$.

The change in the grain size did not exhibit any particular trend. This behaviour can also be explained with dynamic-softening processes, which can be accompanied by the grain coarsening under certain conditions. ${ }^{14,15}$ The changes in the grain size could be caused by a proper combination of a sufficiently high amplitude and an adequate loading time (i.e., a higher number of cycles). It is possible that a slight increase in the grain size at 220 MPa was caused simply by a high stress amplitude, which allowed the grain coarsening to partially develop even during 24.000 cycles. In contrast with this assumption, the changes at $180 \mathrm{MPa}$ could be attributed to more than $7 \times 10^{6}$ cycles, which allowed the grain coarsening to develop at the tested amplitude (which was very close to the estimated fatigue limit). At $160 \mathrm{MPa}$ and $200 \mathrm{MPa}$, the conditions for the development of grain coarsening were probably insufficient so that the grain size remained almost unchanged.

\section{CONCLUSIONS}

Changes of the (sub)structural parameter of finegrained Mg alloy AZ91 processed with ECAP were analysed:

- At lower stress amplitudes, the local lattice distortion and the amount of LAB decreased because of the influence of dynamic-softening processes that counteracted the dislocation accumulation.

- With the increasing stress amplitude (and decreasing number of cycles/cycles to failure), the influence of the dislocation accumulation increased and the softening processes did not fully develop so that both the LAB number fraction and local lattice distortion gradually increased.

- The change in the average grain size did not exhibit any particular trend so that during the cyclic loading below the fatigue limit, the microstructure could be considered as stable.

\section{Acknowledgement}

This work was supported by the specific research project no. FSI-S-14-2511 and the European Regional Development Fund in the framework of research project NETME Centre under the Operational Program Research and Development for Innovation No. CZ.1.5/2.1.00/ 01.002, and within project NETME plus (Lo1202), a project of the Ministry of Education, Youth and Sports under the "National sustainability programme".

\section{REFERENCES}

${ }^{1}$ B. L. Mordike, T. Ebert, Magnesium: Properties - applications potential, Materials Science and Engineering A, 302 (2001), 37-45, doi:10.1016/S0921-5093(00)01351-4

${ }^{2}$ P. Poddar, S. Bagui, K. Ashok, A. P. Murugesan, Experimental investigation on microstructure and mechanical properties of gravitydie-cast magnesium alloys, Journal of alloys and compounds, 695 (2017), 895-908, doi:10.1016/j.jallcom.2016.10.193

${ }^{3}$ H. M. Ruzi, M. Norhamidi, S. Abu Bakar, R. J. Khairur, M. N. Nor Hafiez, A. Sufizar, I. I. M. Halim, A review of workability of wrought magnesium alloys, Advanced Manufacturing Research Group '09 Seminar 3, 2009

${ }^{4}$ K. Kubota, M. Mabuchi, K. Higashi, Review: Processing and mechanical properties of fine-grained magnesium alloys, Journal of Materials Science, 34 (1999), 2255-2262, doi:10.1023/ A: 1004561205627

${ }^{5}$ R. B. Figueiredo, T. G. Langdon, Grain refinement and mechanical behavior of a magnesium alloy processed by ECAP, J. Mater. Sci., 45 (2010), 4827-4836, doi:10.1007/s10853-010-4589-y

${ }^{6}$ J. Stráská, M. Janeček, J. Čížek, J. Stráský, B. Hadzima, Microstructure stability of ultra-fine grained magnesium alloy AZ31 processed by extrusion and equal-channel angular pressing (EX-ECAP), Materials Characterization, 94 (2014), 69-79, doi:10.1016/j.matchar.2014.05.013

${ }^{7}$ H. K. Kim, W. J. Kim, Microstructural instability and strength of an AZ31 Mg alloy after severe plastic deformation, Materials Science and Engineering A, 385 (2004), 300-308, doi:10.1016/j.msea.2004. 06.055 


\section{R. ŠTĚPÁNEK et al.: MICROSTRUCTURAL CHANGES OF ECAP-PROCESSED MAGNESIUM ALLOY AZ91 ...}

${ }^{8}$ H. W. Höppel, M. Kautz, C. Xu, M. Murashkin, T. G. Langdon, R. Z Valiev, H. Mughrabi, An overview: Fatigue behaviour of ultrafinegrained metals and alloys, International Journal of Fatigue, 28 (2006), 1001-1010, doi:10.1016/j.ijfatigue.2005.08.014

${ }^{9}$ S. Fintová, L. Kunz, Fatigue properties of magnesium alloy AZ91 processed by severe plastic deformation, Journal of the Mechanical Behavior of Biomedical Materials, 42 (2015), 219-222, doi:10.1016/j.jmbbm.2014.11.019

${ }^{10}$ L. Wu, G. M. Stoica, H. Liao, S. R. Agnew, E. A. Payzant, G. Wang, D. E. Fielden, L. Chen, P. K. Liaw, Fatigue-property enhancement of magnesium alloy AZ31B through equal-channel-angular pressing, Metallurgical and Materials Transactions A, 38 (2007), 2283-2289, doi:10.1007/s1161-007-9123-8

${ }^{11}$ L. Kunz, P. Lukáš, L. Pantělejev, O. Man, Stability of microstructure of ultrafine-grained copper under fatigue and thermal exposition, Strain, 47 (2011), 476-482, doi:10.1111/j.1475-1305.2009.00710.x
${ }^{12}$ R. Zhu, Y. J. Wu, W. Q. Ji, J. T. Wang, Cyclic softening of ultrafinegrained AZ31 magnesium alloy processed by equal-channel angular pressing, Materials Letters, 65 (2011), 3593-3596, doi:10.1016/ j.matlet.2011.07.111

${ }^{13}$ Z. J. Zhang, P. Zhang, Z. F. Zhang, Cyclic softening behaviours of ultra-fine grained $\mathrm{Cu}-\mathrm{Zn}$ alloys, Acta Materialia, 121 (2016), 331-342, doi:10.1016/j.actamat.2016.09.020

${ }^{14}$ H. W. Höppel, H. Mughrabi, Cyclic deformation and fatigue properties of very fine-grained metals and alloys, International Journal of Fatigue, 32 (2010), 1413-1427, doi:10.1016/j.ifatigue.2009. 10.007

${ }^{15}$ T. Sakai, A. Belyakov, R. Kaibyshev, H. Miura, J. J. Jonas, Dynamic and post-dynamic recrystallization under hot, cold and severe plastic deformation conditions, Progress in Materials Science, 60 (2014), 130-207, doi:10.1016/j.pmatsci.2013.09.002 